\title{
Nové vymezení environmentální gramotnosti a návrh na její mezinárodní hodnocení v PISA 2015
}

\section{Petr Daniš}

\section{Envigogika 8 (3) - Recenzované články/Revieved Papers}

Publikováno/ Published 15. 10. 2013

DOI: http://dx.doi.org/10.14712/18023061.385

\begin{abstract}
Abstrakt:
Tento článek představuje nové vymezení environmentální gramotnosti, které zveřejnila Severoamerická asociace pro environmentální výchovu (NAAEE) v prosinci roku 2011. Stručně zasazuje nové vymezení do kontextu vývoje environmentální výchovy $\checkmark$ mezinárodním prostředí, přibližuje nový popis oblasti environmentální gramotnosti a jeho aplikaci v návrhu na hodnocení environmentální gramotnosti ve výzkumu PISA v roce 2015. Článek zahajuje diskusi o silných a slabých stránkách a další využitelnosti nového vymezení v českém i zahraničním prostředí.
\end{abstract}

\section{Klíčová slova}

environmentální výchova, environmentální gramotnost, hodnocení environmentální gramotnosti, PISA

\begin{abstract}
This article presents a new definition of environmental literacy, published by the North American Association for Environmental Education (NAAEE) in December 2011. It briefly puts the new definition into the context of the development of environmental education on the international stage, introduces the new description to the field of environmental literacy and its application in the design of the evaluation of environmental literacy in PISA 2015. The article initiates a discussion about its strengths and weaknesses and the further utility of this new definition in Czech and foreign contexts.
\end{abstract}

\section{Key words}

environmental education, environmental literacy, environmental literacy assessment, PISA 


\section{Úvod}

Před environmentální výchovou průběžně vyvstává potřeba dobře vymezit oblast, ve které se pohybuje, jasně artikulovat cíle, které sleduje, a navrhnout vhodné způsoby, jak dosahování těchto cílů hodnotit.

Tento článek představuje nové vymezení environmentální gramotnosti, které zveřejnila Severoamerická asociace pro environmentální výchovu (NAAEE) v prosinci roku 2011 (Hollweg ${ }^{1}$ a kol., 2011). Jedním z cílů článku je zasadit toto nové vymezení do kontextu vývoje environmentální výchovy $v$ mezinárodním prostředí, přiblížit popis a uspořádání oblasti environmentální gramotnosti vytvořené NAAEE a ukázat, jak toto vymezení bylo využito v návrhu na hodnocení environmentální gramotnosti ve výzkumu PISA v roce 2015. Druhým cílem je zahájit diskusi o silných a slabých stránkách a využitelnosti tohoto vymezení v českém i mezinárodním prostředí. Cílem článku není podrobně analyzovat a srovnávat jiná vymezení environmentální výchovy a environmentální gramotnosti ani jiné př́stupy k hodnocení environmentální gramotnosti.

\section{Vyjasnění užívaných pojmů}

V tomto článku užíváme pojmy environmentální výchova (environmental education) a environmentální gramotnost (environmental literacy). Tyto pojmy zcela záměrně na začátku článku nedefinujeme. Jedním z cílů článku je nastínit vývoj porozumění environmentální výchově $v$ mezinárodním prostředí a právě na tomto pozadí ukázat nové vymezení environmentální gramotnosti z dílny NAAEE. Uvidíme tak, že se chápání environmentální výchovy postupně proměňuje a teprve v posledních dvou desetiletích bývá jakožto cíl environmentální výchovy chápán právě rozvoj environmentální gramotnosti. Environmentální gramotnost samotnou podrobně vymezíme a popíšeme v oddílu 4., kde představíme její nové vymezení vytvořené NAAEE.

V článku si dále pomáháme výrazy oblast a rámec, at́ už ve spojení s environmentální výchovou či environmentální gramotností. Slovo oblast (domain) naznačuje, že environmentální výchova či gramotnost je určitým polem či doménou, kam něco patří a něco už je za jejími hranicemi. Rámec (framework) označuje určité pojetí a uspořádání toho, z čeho všeho se podle některých autorů environmentální výchova či environmentální gramotnost skládá. Popisuje nejenom její jednotlivé složky či proměnné, ale také se je snaží logicky uspořádat a ukázat vazby mezi nimi. Zatímco v anglické odborné literatuře o environmentální výchově jsou výrazy domain a framework běžné (NAAEE, 2010a, Hollweg a kol., 2011), v české literatuře nejsou výrazy oblast a rámec ve spojení s environmentální výchovou nebo gramotností zatím príliš obvyklé. Je důležité podotknout, že $v$ anglických odborných textech se s těmito výrazy nepracuje jako s odbornými termíny, které vyžaduji svoje definování, ale spíše jako $s$ běžnými slovy, které nám pomáhají v popisu termínů environmentální výchova či environmentální gramotnost.

\footnotetext{
${ }^{1}$ Zahraniční ženská jména používáme v tomto článku v originále a nesnažíme se je počeštit koncovkou -ová.
} 


\section{Vývoj environmentální výchovy a (jejího) hodnocení v mezinárodním prostředí}

Není ambicí tohoto článku popsat vývoj environmentální výchovy, jejího hodnocení i hodnocení obecně v zahraničí vyčerpávajícím zpưsobem a ve všech detailech. Naším cílem je zde tento vývoj částečně přiblížit jako nezbytný kontext umožňující pochopení nového vymezení environmentální gramotnosti vytvořeného NAAEE. Z tohoto důvodu se zaměříme hlavně na tři oblasti, které autoři tohoto nového vymezení identifikovali jako své hlavní zdroje inspirace:

- $\quad$ předchozí rámce vymezující oblast environmentální výchovy;

- nedávné celostátní hodnocení environmentální gramotnosti v USA a dalších zemích;

- program mezinárodního hodnocení studentů (PISA) realizovaný Organizací pro hospodářskou spolupráci a rozvoj (OECD).

\subsection{Vývoj definování environmentální výchovy}

Základní a široce přijímaná východiska pro vymezení cílů i strategií environmentální výchovy představují Bělehradská charta a Tbiliská deklarace. Bělehradská charta (UNESCO, 1975) stanovila jako cíl environmentální výchovy "vychovat takové světové obyvatelstvo, které si uvědomuje a zajímá se o životní prostředí a problémy s ním spojené, a které má poznatky, dovednosti, postoje, motivace a odhodlání individuálně i společně rešit současné problémy a předcházet novým problémům". Tbiliská deklarace (UNESCO, 1978) vyzdvihla a popsala pět kategorií cílů environmentální výchovy: povědomí (o životním prostredí a jeho problémech), znalosti (porozumění životnímu prostředí a jeho problémům), postoje (hodnoty a motivace umožňující podílet se na zlepšování a ochraně životního prostředí), dovednosti (rozpoznat a řešit problémy životního prostředí) a participaci (aktivně se podílet na řešení environmentálních problémů).

Pozdější vymezení environmentální výchovy na tato východiska navazují a doplňují je. S narůstajícím objemem výzkumů a evaluací různých vzdělávacích programů se ukazuje, že původní východisko neobsahuje všechny proměnné, které jsou pro environmentální výchovu důležité (např. environmentální senzitivitu, přesvědčení o možnosti svým jednáním něco změnit apod.). $V$ anglosaském prostředí tak od konce 70 . let postupně vzniká celá řada rámců, které ve snaze o doplnění nových poznatků popisují oblast environmentální výchovy a naznačují její dělení do různých podoblastí. V roce 1990 např́klad publikují Hungerford a Volk vlivný model environmentálně odpovědného jednání (responsible environmental behaviour - REB), ve kterém popisují znalosti, dovednosti a další složky související s afektivitou a chováním a organizují je do tří úrovní - vstupních proměnných, vlastnických proměnných a proměnných vlivu (Hungerford a Volk, 1990). Některé rámce definující environmentální výchovu vznikají v širších pracovních skupinách (např. v roce 1994 práce tzv. Konsorcia pro gramotnost $v$ environmentální výchově ve složení Hungerford, Volk, Wilke, Champeau, Marcinkowski, May, Bluhm a McKeown-Ice), další za specifickým účelem jako třeba zavedení a rozšírení nového vzdělávacího programu (např. Projekt WILD v roce 1986, Projekt WET v roce 1993 apod.). V roce 1995 Bara Simmons uvádí ve své analýze celkem 20 různých rámců vymezujících environmentální výchovu a hledá základní společné rysy a podoblasti, kterými se většina z nich vyznačuje (přehled rámců je také $\checkmark$ př́loze publikace Excellence in Environmental Education: Guidelines for Learning (Pre K12) - NAAEE, 2010a). Tento průsečík potom tvoří základ pro pojetí oboru ve standardech (guidelines) pro environmentální výchovu, jež jsou publikovány NAAEE od roku 1999 
$\checkmark$ rámci projektu, který si klade za cíl popsat podobu vysoce kvalitní realizace environmentální výchovy (NAAEE, 2000, 2004, 2009, 2010a, 2010b, 2010c).

Zajímavým vývojem prochází sama definice hlavního cíle environmentální výchovy. Bělehradská charta a Tbiliská deklarace se krátké definici vyhýbá a cíl vymezuje výčtem cílů stanovujících celkový rámec environmentální výchovy (povědomí, znalosti, dovednosti, postoje, motivace...) (UNESCO, 1975 a 1978). Hungerford a Volk (1990) vymezují konečný cíl environmentální výchovy jako environmentálně odpovědné chování (jednání) a tato definice se rozšiřuje $v$ anglosaském prostředí především $v 90$. letech minulého století. $\checkmark$ novějších dokumentech je konečný cíl environmentální výchovy popisován jako rozvoj environmentální gramotnosti či environmentálně gramotného občanství (NAAEE, 2009 a 2010a). Můžeme se dohadovat, co je hlavním důvodem tohoto posunu, zda rozšiřování konceptu gramotnosti $v$ celé oblasti vzdělávání, nebo určitá kritika behaviorismu snášející se na každé vzdělávací úsilí, jež o sobě deklaruje, že jeho cílem je změna chování. Je dobré si však uvědomit, že obě definice svým způsobem jen ukazují dvě strany téže mince: zdůrazňují bud' environmentálně odpovědné chování, ke kterému vede cesta přes rozvoj znalostí, dovedností či kompetencí a dalších afektivních složek (tedy vlastně přes rozvoj environmentální gramotnosti), nebo právě rozvoj environmetální gramotnosti, která umožňuje dělat informovaná rozhodnutí týkající kvality životního prostředí a tedy nakonec environmentálně odpovědně jednat. Záběr a strategie zůstávají u koncepcí používajících obě definice podobné, environmentální výchova se stále zaměřuje na rozvoj obdobných dispozic, znalostí, dovedností či kompetencí.

\subsection{Vývoj hodnocení environmentální gramotnosti}

Hodnocení jednotlivých programů environmentální výchovy se zpracovávají již od 70. let 20. století. Od té doby také postupně vznikají různé nástroje využívané na měření dílčích proměnných environmentální výchovy. Např. Nové environmentální paradigma NEP (Dunlap a Van Liere, 1978) se využívá zřejmě jako nejrozšířenější nástroj na měření pro-environmentálních postojů. Snaha hodnotit environmentální gramotnost $v$ její celé šíri a na úrovni celých populací se však rodí spiše až na samotném konci minulého tisíciletí. Ve Spojených státech jsou vyvinuty nástroje na hodnocení environmentální gramotnosti studentů ve věku odpovídajícím zhruba 2. stupni základních škol (Middle School Environmental Literacy Instrument - MSELI) a ve věku odpovídajícím zhruba našim středním školám (Secondary School Environmental Literacy Instrument - SSELI). První celonárodní hodnocení reflektující široké pochopení environmentální výchovy se objevují $\vee$ Koreji $\vee$ roce 2005, v Izraeli v roce 2008 a v Turecku v roce 2009. Od roku 2008 v USA postupně probíhá několik fází národního výzkumu environmentální gramotnosti (National Environmental Literacy Assessment Project - NELA), ve kterém se realizují výběrová šetření na randomizovaném vzorku žáků 6. a 8. ročníků vycházející z nástroje MSELI, zkoumá se vliv zavedených programů environmentální výchovy na environmentální gramotnost apod. (popsáno podle Hollweg a kol., 2011). Tento nový trend přináší vyšší požadavky na dobré vymezení environmentální gramotnosti jako celku i na rozlišení jejích dílčích složek, které je možné ověřovat $\mathrm{v}$ podobných masových šetřeních. Na pozadí těchto potřeb vzniká i nové vymezení environmentální výchovy, které představíme v oddíle 4.

\subsection{PISA - mezinárodní hodnocení gramotností žáků}

Na poli hodnocení výsledků ve vzdělávání se na konci minulého tisíciletí začal rodit dnes asi nejvlivnější nástroj na hodnocení žáků v mezinárodním měřítku. Program pro mezinárodní hodnocení žáků (Programme for International Student Assessment - PISA) je v Organizaci pro hospodářskou spolupráci a rozvoj (OECD) veden snahou zaměřit hodnocení nikoliv na ověřování výsledků školního vzdělávání, ale na zjištóování znalostí a doved- 
ností, které žáci skutečně potřebují k životu (OECD, 2013a). Zahájení programu předcházely debaty tvůrců vzdělávacích politik a akademiků na půdě $\mathrm{OECD}$, zda je současná škola schopná vybavit žáky kompetencemi potřebnými pro život $v 21$. století. Uskutečnil se $i$ projekt zaměřený na definování a výběr těchto kompetencí potřebných pro uplatnění $\checkmark$ životě a práci (Defining and Selecting Competencies - DeSeCo), do kterého byla zapojena řada významných osobností z různých oborů (OECD, 2005).

Program PISA se soustředí na zjištování úrovně čtenářské, matematické a přírodovědné gramotnosti chápaných jako schopnost funkčního používání určitých znalostí (obsahů) a dovedností (kompetencí) v nejrůznějších situacích (kontextech). Testování probíhá od roku 2000 každé tři roky na vzorku patnáctiletých a účastní se ho rostoucí počet zemí. Výzkum se pokaždé věnuje všem třem uvedeným gramotnostem (což představuje možnost pravidelně srovnávat data a zachycovat vývoj), zároveň se do hloubky zaměřuje na jednu z nich (tak Ize získat dostatečné množství informací o dané gramotnosti), a navíc nabízí i jednu další specifickou oblast jako doplňkovou, volitelnou část výzkumu (OECD, 2013a).

Výzkum PISA se řídí vysokými standardy kvality a podle některých odborníků „představuje z metodologického hlediska to nejlepší, co je v oblasti mezinárodních výzkumů vědomostí a dovedností $k$ dispozici." Kvalita se zajištúuje celou řadou opatření: výzkum se zaměřuje na rozmanitost testových úloh z hlediska kulturních kontextů, administrace se ř́dí př́snými pravidly a je kontrolována nezávislými kontrolory kvality, otevřené úlohy jsou hodnoceny dvěma nezávislými hodnotiteli na základě přesných pokynů a náročného školení a je vyhodnocována jejich shoda atd. (Straková, 2011).

V roce 2006 byl výzkum PISA poprvé zaměřen na prírodovědnou gramotnost, do které zahrnul tyto složky (ÚIV, 2006):

- přírodovědné vědomosti a jejich využívání k rozpoznávání témat, získávání nových vědomostí, vysvětlování přirodovědných jevů a vyvozování podložených závěrů o tématech vztahujících se $\mathrm{k}$ prírodním vědám,

- znalost charakteristických rysů vědy jako formy lidského poznání a zkoumání,

- povědomí o tom, jak prírodní vědy a technika utvářejí naše materiální, myšlenkové a kulturní prostředí,

- ochotu zabývat se myšlenkami a tématy souvisejícími s prírodními vědami a přemýšlet o nich.

Celkový rámec pro hodnocení prírodovědné gramotnosti ve výzkumu obsahoval několik položek, které prolínaly do oblasti environmentální výchovy (např. vědomosti o ekosystémech a biosféře, životní prostředí jako jeden z pěti kontextů pro testové úlohy, postoje vưči zdrojům a životnímu prostředí). Výzkum přinesl první mezinárodně srovnatelná data o tom, co studenti vědí o životním prostředí a s ním spojených problémech, odkud čerpají tyto znalosti, jaké mají postoje k environmentálním otázkám a jak souvisí jejich výsledky z oblasti vědy o životním prostředí s jejich postoji k němu. Shrnutí hlavních zjištění $z$ analýzy těchto dat představila publikace Green at Fifteen (OECD, 2009). Pravděpodobně $\vee$ návaznosti na tyto trendy se také zrodil návrh, aby oblast environmentální gramotnosti byla př́mo zařazena jako doplňková, volitelná část do výzkumu PISA 2015, kde hlavní oblastí zkoumání bude opět prírodovědná gramotnost. 


\section{Projekt NAAEE: nové vymezení environmentální gramotnosti a rámce na její hodnocení}

Cílem projektu realizovaného pod hlavičkou NAAEE bylo vytvořit nový, dobře srozumitelný a na výzkumných zjištěních založený popis environmentální gramotnosti a využít ho k tvorbě rámce pro hodnocení environmentální gramotnosti. Na projektu se podíleli odborníci na výzkum a hodnocení v oblastech environmentální výchovy, studia přírodních i společenských věd a z př́buzných vědeckých oborů. Interní tým pracoval ve složení Karen Hollweg (NAAEE), Jason Taylor (Nature Talks, L.L.C.), Rodger Bybee (Biological Science Curriculum Study) Thomas Marcinkowski (Florida Institute of Technology), William McBeth (University of Wisconsin-Patteville) a Pablo Zoido (OECD/PISA), další experti poskytovali zpětnou vazbu, připomínky a náměty k prvním návrhům textů.

Práce Developing a framework for assessing environmental literacy (Hollweg a kol., 2011) je zajímavá nejen svým výsledkem, ale i svým postupem. Autoři pečlivě zvažují existující poznatky z oblasti environmentální výchovy. Otevřeně si kladou otázky a ukazují obtíže, před kterými stojí, a zdůvodňují odpovědi, ke kterým se nakonec přikloní. Práce využívá nejlepší poznatky minulosti, vytváří nový popis oblasti environmentální gramotnosti jako produkt současnosti; dává ho k dispozici a popisuje jeho možné budoucí využití. Zásadní je i to, že se autoři snaží, jak nejlépe jsou toho schopni, zachytit současné porozumění oboru, v žádném případě však jejich práce nepřináší žádnou správnou či navždy platnou definici environmentální výchovy ani environmentální gramotnosti.

V následujících řádcích nejprve podrobněji představíme jak nové vymezení environmentální gramotnosti, tak i popis a uspořádání této oblasti. Dále ukážeme návrh rámce pro hodnocení environmentální gramotnosti ve výzkumu PISA v roce 2015, který z nového vymezení environmentální gramotnosti vychází.

\subsection{Vymezení oblasti environmentální gramotnosti}

Nový rámec NAAEE definuje environmentálně gramotnou osobu „jako někoho, kdo, jak samostatně, tak spolu s druhými, dělá informovaná rozhodnutí týkající se životního prostředí; je ochotný jednat na základě těchto rozhodnutí, aby zlepšil kvalitu života (wellbeing) dalších jedinců, společnosti a kvalitu globálního životního prostředí; a podílí se na občanském životě". Environmentálně gramotní lidé mají v různém měřítku:

- znalosti a porozumění týkající se širokého spektra environmentálních pojmů, problémů a konfliktů,

- $\quad$ sadu kognitivních a afektivních dispozic,

- $\quad$ sadu kompetencí (kognitivních dovedností a schopností),

- $\quad$ vhodné behaviorální strategie, aby na základě těchto znalostí a tohoto porozumění dospěli k rozumným a efektivním rozhodnutím v celé škále environmentálních kontextů.

Všechny tyto složky (kognitivní - znalosti, dovednosti a schopnosti; afektivní a behaviorální) jsou přitom ve vzájemné vazbě, ovlivňují se a u každého jedince se mohou postupně rozvíjet během jeho života. To znamená, že určitý člověk není bud' environmentálně gramotný, nebo negramotný - ale postupně se rozvíjí na kontinuu environmentální gramotnosti. 
Schéma 1 podrobněji zachycuje jednotlivé složky environmentální gramotnosti a vztahy mezi nimi. Autoři studie (Hollweg a kol., 2011) dále všechny uvedené položky detailně popisují, vysvětlují vazby mezi nimi i důvody pro jejich zařazení do celkového rámce a vše dokládají seznamy odborné literatury a výzkumu, o které se ve svých tvrzeních opírají.

(Ke schématu se váže ještě jedna terminologická poznámka. Výraz environmental issues $v$ tomto schématu a dále překládáme jako environmentální problémy. Činčera (2011) se snaží v českém prostředí pro environmental issues zavádět termín environmentální konflikty (viz též Pastorová a kol., 2011), v protikladu k environmentálním problémưm - environmental problems. Potíž je $v$ tom, že tomto prezentovaném schématu se $v$ angličtině vědomě nepracuje s rozlišením problems - problémy a issues - konflikty vznikající při jejich řešení; vše nasvědčuje spíše tomu, že výraz issues zde ve své obecnosti zahrnuje oba aspekty. Potom se nám překlad environmentální problémy zdá být vhodnější než environmentální konflikty.) 
Schéma 1: Oblast environmentální gramotnosti (Hollweg a kol., 2011)

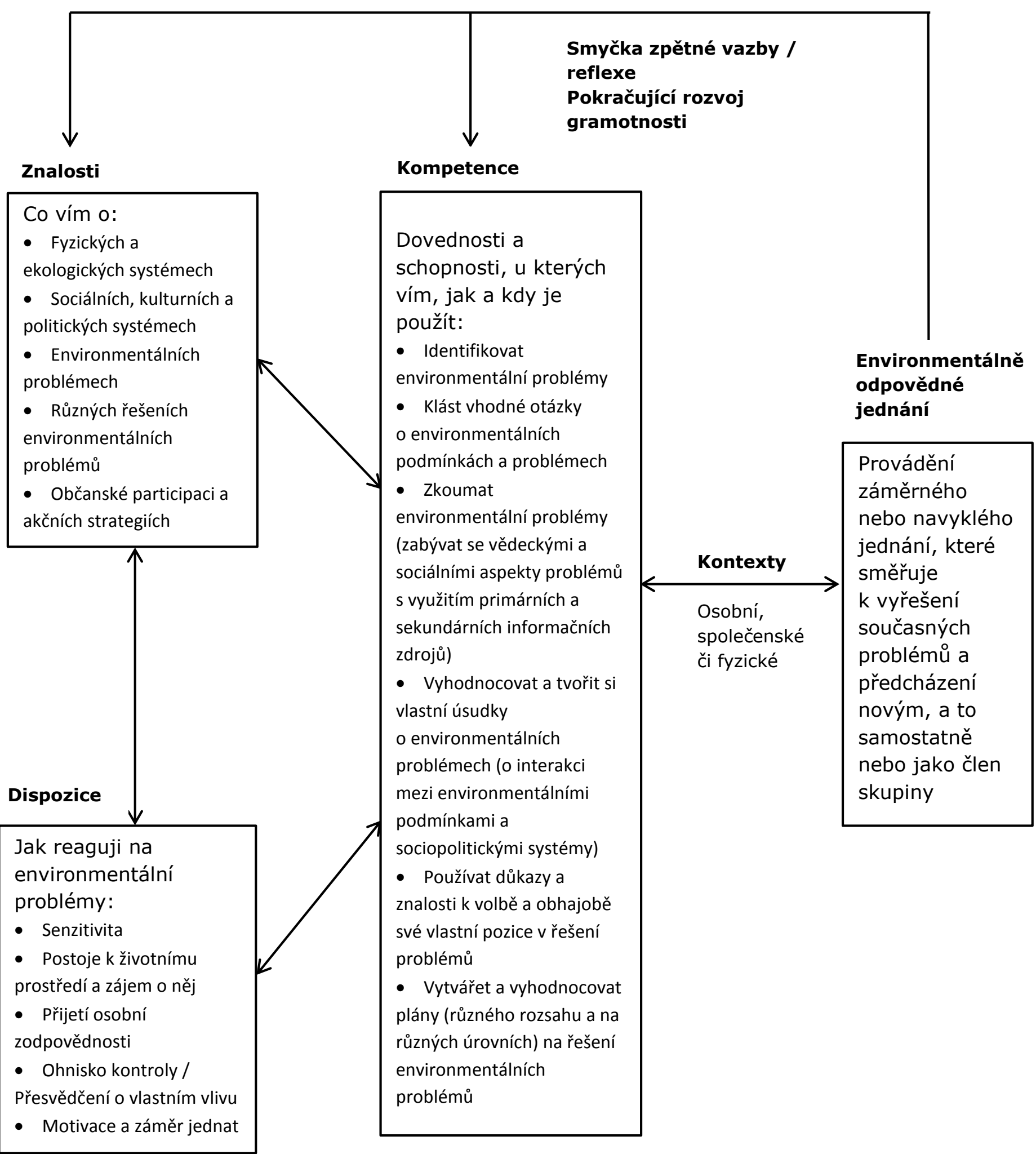




\subsection{Návrh rámce na hodnocení environmentální gramotnosti v PISA 2015}

Ne všechny složky a proměnné environmentální gramotnosti Ize vyhodnocovat v dotazníkových šetřeních či testech. Pro výzkumy typu PISA navíc hraje roli i proveditelnost takového šetření $v$ poměrně krátkém čase, což také ovlivňuje množství složek, které je možné vyhodnocovat. Celý návrh je založen na předpokladu, že hodnocení environmentální gramotnosti bude zařazeno do výzkumu PISA 2015 jako doplňková oblast k hodnocení př́rodovědné gramotnosti a bude mu věnováno 60 minut $z$ celkového času testu. Výše představený popis oblasti environmentální gramotnosti je proto třeba zjednodušit či zúžit, při tom je však důležité vybrat její zásadní prvky, aby prováděné šetření skutečně stále hodnotilo úroveň environmentální gramotnosti. Autoři navrhují soustředit se na čtyři vzájemně související složky environmentální gramotnosti: kontexty, kompetence, environmentální znalosti a dispozice vưči životnímu prostředí. Jejich základní strukturu zachycuje schéma 2.

Schéma 2: Návrh rámce pro hodnocení environmentální gramotnosti v PISA 2015 (Hollweg a kol., 2011)

\begin{tabular}{|c|c|c|c|c|}
\hline \multirow[t]{2}{*}{ Kontexty } & \multirow[b]{2}{*}{ vyžadují } & Kompetence & & $\begin{array}{l}\text { Environmentální } \\
\text { znalosti }\end{array}$ \\
\hline & & $\begin{array}{l}\text { Identifikovat } \\
\text { environmentální } \\
\text { problémy }\end{array}$ & \multirow[b]{2}{*}{$\begin{array}{l}\text { jak projevuji } \\
\text { kompetence, } \\
\text { závisí na }\end{array}$} & $\begin{array}{l}\text { Co vím o: } \\
\text { - fyzických, ekologických } \\
\text { systémech } \\
\text { - environmentálních } \\
\text { problémech } \\
\text { - sociopolitických systé- } \\
\text { mech } \\
\text { - strategiích, jak řešit } \\
\text { environmentální problémy }\end{array}$ \\
\hline \multirow{2}{*}{$\begin{array}{l}\text { Lokální, } \\
\text { regionální } \\
\text { nebo globál- } \\
\text { ní situace, } \\
\text { které zahr- } \\
\text { nují životní } \\
\text { prostředí }\end{array}$} & & $\begin{array}{l}\text { Vyhodnocovat } \\
\text { možná řešení } \\
\text { environmentál- } \\
\text { ních problémů }\end{array}$ & & $\begin{array}{l}\text { Dispozice vůči } \\
\text { životnímu pro- } \\
\text { středí }\end{array}$ \\
\hline & & $\begin{array}{l}\text { Navrhovat a } \\
\text { zdůvodňovat } \\
\text { činnosti, které } \\
\text { řeší environmen- } \\
\text { tální problémy }\end{array}$ & ovlivňuje & $\begin{array}{l}\text { Jak reaguji na environ- } \\
\text { mentální problémy: } \\
\text { - zájem } \\
\text { - } \text { senzitivita } \\
\text { - ohnisko kontroly } \\
\text { - odpovědnost } \\
\text { - záměr jednat }\end{array}$ \\
\hline
\end{tabular}

Hollweg a kol. zdůrazňují, že hodnocení environmentální gramotnosti má obsáhnout dostatečnou šiŕi různých kontextů, ve kterých dochází k jejím projevům. Kontexty by měly zahrnovat situace od lokálních po globální, řadu témat od biodiverzity přes prírodní zdroje po využívání půdy a měly by se týkat jak osobní, tak občanské odpovědnosti. Jejich návrh kontextů zachycuje tabulka 1. 
Tabulka 1. Kontexty pro uplatnění environmentální gramotnosti (Hollweg a kol., 2011)

\begin{tabular}{|c|c|c|c|}
\hline & Lokální & Regionální & Globální \\
\hline Biodiverzita & Flora a fauna & $\begin{array}{l}\text { Ohrožené druhy, } \\
\text { úbytek stanovišt' } \\
\text { pro organismy, } \\
\text { exotické invazní } \\
\text { druhy }\end{array}$ & $\begin{array}{l}\text { Ekologická udrži- } \\
\text { telnost, udržitelné } \\
\text { využívání druhů }\end{array}$ \\
\hline Populační růst & $\begin{array}{l}\text { Růst, naroze- } \\
\text { ní/smrt, emigrace, } \\
\text { imigrace }\end{array}$ & $\begin{array}{l}\text { Udržování lidské } \\
\text { populace, rozmís- } \\
\text { tění populace, } \\
\text { přelidnění }\end{array}$ & $\begin{array}{l}\text { Růst populace a } \\
\text { jeho sociální, eko- } \\
\text { nomické a envi- } \\
\text { ronmentální dů- } \\
\text { sledky }\end{array}$ \\
\hline Přírodní zdroje & $\begin{array}{l}\text { Osobní spotřeba } \\
\text { materiálů }\end{array}$ & $\begin{array}{l}\text { Produkce a distri- } \\
\text { buce jídla, vody, } \\
\text { energie }\end{array}$ & $\begin{array}{l}\text { Udržitelné využívá- } \\
\text { ní obnovitelných a } \\
\text { neobnovitelných } \\
\text { zdrojů }\end{array}$ \\
\hline $\begin{array}{l}\text { Kvalita životního } \\
\text { prostředí a zdraví }\end{array}$ & $\begin{array}{l}\text { Dopady využívání } \\
\text { a odkládání mate- } \\
\text { riálů na kvalitu } \\
\text { ovzduší a vody }\end{array}$ & $\begin{array}{l}\text { Zacházení } \\
\text { s tekutým a pev- } \\
\text { ným odpadem, } \\
\text { dopady na životní } \\
\text { prostředí }\end{array}$ & $\begin{array}{l}\text { Udržitelnost eko- } \\
\text { systémových slu- } \\
\text { žeb }\end{array}$ \\
\hline $\begin{array}{l}\text { Přírodní pohromy a } \\
\text { extrémní počasí }\end{array}$ & $\begin{array}{l}\text { Rozhodnutí o vý- } \\
\text { stavbě v oblastech } \\
\text { ohrožených po- } \\
\text { vodněmi, př́livo- } \\
\text { vými vlnami či } \\
\text { silným větrem }\end{array}$ & $\begin{array}{l}\text { Náhlé proměny } \\
\text { (např. zemětřese- } \\
\text { ní), pomalé pro- } \\
\text { měny (např. po- } \\
\text { břežní eroze), rizi- } \\
\text { ka a výhody }\end{array}$ & $\begin{array}{l}\text { Klimatická změna, } \\
\text { extrémní projevy } \\
\text { počasí }\end{array}$ \\
\hline Využívání půdy & $\begin{array}{l}\text { Ochrana zeměděl- } \\
\text { ské půdy a přírod- } \\
\text { ních oblastí }\end{array}$ & $\begin{array}{l}\text { Dopady využívání } \\
\text { a odklonů vody, } \\
\text { vodních toků a } \\
\text { zátopových území }\end{array}$ & $\begin{array}{l}\text { Tvorba a ztráta } \\
\text { ornice, ztráta ob- } \\
\text { dělávané půdy }\end{array}$ \\
\hline
\end{tabular}

Ve shodě s náročnou metodikou výzkumu PISA nás autoři studie dále provázejí několika dalšími důležitými rozhodnutími, které je třeba provést před samotnou přípravou otázek a úloh $\mathrm{k}$ hodnocení environmentální gramotnosti podle navrženého rámce. Popisují celkovou strukturu hodnotících dotazníků, navrhují procentuální zastoupení kontextů v testovacích úlohách a vzájemné proporce úloh zaměřených na jednotlivé složky environmentální gramotnosti, věnují se otázce vhodného formátu testových odpovědí (poměr otázek s výběrem odpovědi a otázek s tvorbou odpovědi apod.) tak, aby bylo hodnocení co nejvěrnější a nejspravedlivější a zároveň dobře proveditelné. 


\section{Diskuse}

$\checkmark$ následující diskusi bychom se rádi zaměřili na tři hlavní témata: na shrnutí silných a možných slabých stránek nového vymezení environmentální gramotnosti; na možnosti využití tohoto nového vymezení $v$ českém prostředí; a na to, jak se vyvinula situace ohledně zařazení environmentální gramotnosti do mezinárodního hodnocení PISA.

\subsection{Silné a slabé stránky nového vymezení environmentální gramotnosti}

Za nejsilnější stránku nového vymezení environmentální výchovy v projektu NAAEE považujeme těsnou návaznost na předchozí rámce a především na výzkumy týkající se environmentální výchovy a gramotnosti. Za shrnujícím popisem a organizací oblasti environmentální gramotnosti zachyceným na pouhé jedné straně na schématu 1 stojí opravdu velké množství odborné literatury (seznam použité literatury obsahuje kolem 250 titulů), které autoři zohlednili při jeho vypracování. Každá dílči složka environmentální gramotnosti, která se objevuje na schématu, je podrobně vysvětlena a autoři její zařazení zdůvodňují existujícími výzkumy. Autoři nám tak předkládají nejenom výsledek své práce - celkové schéma oblasti environmentální gramotnosti - ale také odhalují proces, jakým k výsledku dospěli, a zdůvodňují svoji volbu výsledky výzkumů. Zdá se nám, že tento postup není zcela obvyklý u mnoha předchozích rámců definující environmentální výchovu a že množství sebraných důkazů, o které se autoři opírají při tvorbě nového vymezení, je nadstandardní.

Další silnou stránku, související s tou předchozí, je samotný tým autorů a dalších odborníků, který nové vymezení vytvořil. $v$ interním týmu se scházejí lidé, kteří do něj přinášejí zkušenosti s tvorbou řady předchozích rámců definujících environmentální výchovu (Marcinkowski), s realizací nedávných národních výzkumů environmentální gramotnosti v USA a v Turecku (McBeth a Marcinkowski) nebo s pojetím gramotností ve výzkumu PISA (Zoido). Práce interního týmu byla před svou finalizací podstoupena rozsáhlému připomínkování dalších odborníků na environmentální výchovu, hodnocení výsledků ve vzdělávání, i z príbuzných přírodovědných i humanitně orientovaných oborů. Nevíme o žádném jiném rámci vymezujícím environmentální gramotnost, který by při své přípravě prošel tak intenzivní a širokou odbornou diskusí.

Za silnou stránku Ize považovat i to, že nový popis oblasti environmentální gramotnosti je vytvářen rovnou s ohledem na potřeby jejího hodnocení. Po kapitole představující nové vymezení environmentální gramotnosti následuje kapitola, ve které autoři ukazují, jak Ize toto vymezení použít při hodnocení environmentální gramotnosti v PISA (Hollweg a kol., 2011). Je to poprvé, kdy je oblast environmentální gramotnosti popsána a organizována obdobně jako jiné gramotnosti zařazené do výzkumu PISA. Návrh na hodnocení environmentální gramotnosti v PISA však můžeme chápat též jako př́klad toho, jak je možné nový popis oblasti environmentální gramotnosti využít i při tvorbě dalších možných hodnotících nástrojů.

Mohlo by se zdát, že poslední uvedená silná stránka může představovat i slabinu. Není ohled na hodnocení v novém popisu a organizaci oblasti environmentální gramotnosti přiliš silný, a nedochází tak $\mathrm{k}$ jejímu prílišnému zúžení? Myslíme si, že tomu tak není. $\checkmark$ představeném popisu environmentální gramotnosti jsou zastoupeny i obtižně hodnotitelné dispozice, postoje a kompetence. Autoři nového vymezení si navíc tohoto úskalí jsou velmi dobře vědomi. Vytváŕejí popis opravdu široce pojaté oblasti environmentální gramotnosti. Rozhodnutí, na co všechno z této oblasti se zaměřit při tvorbě konkrétních nástrojů na hodnocení environmentální gramotnosti, stojí vždy až na tvưrcích těchto hodnotících nástrojů. Autoři nového vymezení environmentální gramotnosti nám ukazují, jak sami 
postupují při tvorbě návrhu na hodnocení environmentální gramotnosti v PISA. Zde pochopitelně ze všech složek environmentální gramotnosti vybírají jen některé - ty, které alespoň dílčím způsobem bude možné hodnotit ve výzkumu PISA, s ohledem na časové, organizační, technické i finanční možnosti, které PISA nabízí. Přitom se ovšem snaží postupovat tak, aby vybrané složky environmentální gramotnosti, na které se hodnocení zaměří, stále reprezentativně pokrývaly celou oblast environmentální gramotnosti, tak, jak ji předtím definovali. Tento způsob práce při př́pravě určitého hodnotícího nástroje je velmi transparentní. Můžeme vidět nejenom to, na jaké jednotlivé složky environmentální gramotnosti se hodnocení zaměří, ale také to, do jaké míry toto zaměření pokrývá celkovou oblast environmentální gramotnosti.

\subsection{Možnosti využití nového vymezení environmentální gra- motnosti v českém prostředí}

V České republice se nám nabízí zajímavá možnost podrobně srovnat vymezení oblasti environmentální gramotnosti v projektu NAAEE s Doporučenými očekávanými výstupy prưřezového tématu environmentální výchova a Cíli a indikátory environmentálního vzdělávání, výchovy a osvěty. Oba tyto dokumenty publikované v roce 2011 se snaží jasně definovat a uspořádat cíle a podoblasti environmentální výchovy a představují tak de facto první podrobné rámce pro vymezení environmentální výchovy $v$ českém prostředí.

Doporučené očekávané výstupy průřezového tématu environmentální výchova (Pastorová a kol., 2011), jež vznikly $\vee$ gesci Ministerstva školství, mládeže a tělovýchovy (respektive jeho prímo řízeného Výzkumného ústavu Pedagogického), stanovují cíle a podrobnější očekávané výstupy pro učení environmentální výchovy $v$ základních školách a gymnáziích. Dokument definuje 5 hlavních oblastí environmentální výchovy (které vzhledem $\mathrm{k}$ potřebě návaznosti na rámcové vzdělávací programy nazývá kličcvá témata), a to senzitivitu, zákonitosti, problémy a konflikty, výzkumné dovednosti a akční strategie. Dokument Cíle a indikátory pro environmentální vzdělávání, výchovu a osvětu v České republice (Broukalová a kol., 2011) byl vytvořen pro změnu v gesci Ministerstva životního prostředí širší pracovní skupinou; stanovuje cíle EVVO, včetně dílčích cílů a jejich vysvětlení, a navrhuje možné indikátory pro posuzování, zda je těchto cílů úspěšně dosahováno. Dokument popisuje tyto základní oblasti EVVO: vztah k prírodě, vztah k místu, ekologické děje a zákonitosti, environmentální problémy a konflikty a připravenost jednat ve prospěch životního prostředí. Ačkoli se oba dokumenty ve svém přístupu liší a obsahují zčásti jiné oblasti i dílčí cíle environmentální výchovy, jejich základní pojetí se shoduje. Zároveň jsou oba dokumenty inspirovány anglosaskými rámci pro environmentální výchovu, byt́ místy tyto rámce přesahují (napríklad zařazením problematiky kontaktu s prírodou či intepretace př́rodního a kulturního bohatství v druhém zmíněném dokumentu).

Mezi vymezením environmentální gramotnosti podle NAAEE a vymezením environmentální výchovy $v$ obou českých dokumentech najdeme některé velké rozdíly. Zatímco pro NAAEE je centrálním pojmem environmentální gramotnost (kterou $v$ jiných publikacích označují jako cíl environmentální výchovy), ani v jednom z českých dokumentů se tento pojem vůbec nevyskytuje (oba definují cíl environmentální výchovy jako rozvoj kompetencí potřebných pro environmentálně odpovědné jednání). Také organizace oblasti environmetální gramotnosti u NAAEE a oblasti environmentální výchovy $v$ českých dokumentech se na první pohled liší. Základní členění environmentální gramotnosti od NAAEE zahrnuje dispozice, znalosti a kompetence, které používáme $v$ určitých kontextech za účelem environmentálně odpovědného jednání. Základní členění environmentální výchovy v českých dokumentech zahrnuje podoblasti jako je vztah $\mathrm{k}$ prrírodě, ekologické děje a zákonitosti, environmentální problémy a konflikty apod. Na druhou stranu se však zdá, že české dokumenty sdílejí s tím americkým mnohá myšlenková východiska. Např́íklad je patrné, že i české 
dokumenty berou $v$ potaz předchozí rámce definující environmentální výchovu, které jsou známé $v$ mezinárodním měřítku. Podrobná analýza srovnávající české dokumenty s americkým přesahuje ovšem záměr tohoto článku.

Druhá významná možnost, jak využívat nové vymezení podle NAAEE v českém prostředí, se nabízí v souvislosti s výzkumy environmentální gramotnosti. Termín environmentální (případně ekologická) gramotnost se totiž v českém prostředí vyskytuje především ve výzkumech, ve kterých se ověřuje, jak velkou environmentální gramotnost určitá skupina lidí vykazuje. $\vee$ různých výzkumech je však environmentální gramotnost definována různě, stejně jako se používají velmi rozdílné nástroje a otázky $\mathrm{k}$ jejímu hodnocení (např. Činčera a Štěpánek, 2007, Matějček a Bartoš, 2012, Dvořáčková a Ryplová, 2012). Některé výzkumy využívají nebo částečně využívají Nové environmentální paradigma (NEP) jako nástroj na měření environmentálních postojů. Některé výzkumy i s ohledem na vývoj v zahraničí usilují o postižení více oblastí, jako jsou různé znalosti či dovednosti, environmentální postoje a proenvironmentální chování. Diskutuje se také otázka vhodnosti přejímání a překládání zahraničních hodnotících nástrojů, které byly vyvinuty v jiném kulturním okruhu i jiném kontextu environmentální výchovy (např. Franěk, 2012). Jeden z nejnovějších výzkumů se snaží vyvinout nový evaluační nástroj, který by odpovídal českému prostředí, a proto pokrýval všechny oblasti obsažené $v$ dokumentu Doporučené očekávané výstupy environmentální výchovy (Dvořáčková a Ryplová, 2012).

Nové vymezení oblasti environmentální gramotnosti, které jsme zde představili, nám může velmi dobře posloužit při interpretaci již existujících i při tvorbě nových výzkumů zjišt́ujících úroveň environmentální gramotnosti u různých skupin lidí - žáků, učitelů, obyvatel určitého regionu apod. Je až pozoruhodné, jak se i v současnosti různé výzkumy environmentální gramotnosti $v$ České republice velice liší podle toho, jak tomuto pojmu jejich autoři rozumí - což určuje, co ve skutečnosti měří -, a přitom všechny vytváŕejí závěry o úrovni environmentální gramotnosti určitých lidí. Zde uvedené schéma oblasti environmentální gramotnosti mưže poskytnout referenční rámec pro posouzení, zda české výzkumy odpovídají současnému chápání environmentální gramotnosti na mezinárodním poli. Mưže také pomoci přesně určit a popsat, jaké složky environmentální gramotnosti daný výzkum postihuje a jaké naproti tomu opomíjí.

Představený projekt NAAEE, pro nás může být zároveň bohatým zdrojem inspirace, jak vytvářet podobné dokumenty vymezující oblast environmentální výchovy, respektive navrhovat výzkumy ověřující úspěšnost našeho vzdělávacího snažení. Autoři mapují svá východiska a zdroje inspirace, vysvětlují každou složku zařazenou do nového vymezení environmentální gramotnosti, opírají její zařazení o výsledky výzkumu, odhalují otázky, které si kladou, a zdůvodňují rozhodnutí, jež provádějí. Pečlivost, poctivost a odborná erudice při tomto postupu demonstrují vysoké standardy, které bychom na sebe měli klást při tvorbě obdobných dokumentů a výzkumů i v České republice.

\subsection{Environmentální gramotnost jako součást PISA}

Bude skutečně úroveň environmentální gramotnosti zjištóvána v mezinárodním výzkumu PISA v roce 2015 podle zde představeného návrhu? Nakonec nebude. Podle informací zveřejněných OECD $k$ výzkumu PISA až $v$ průběhu psaní tohoto článku bude $v$ roce 2015 testována prírodovědná gramotnost, která bude doplněna oblastí týmové spolupráce při řešení problémů $(O E C D, 2013 b)$. Přitom dlouho vše nasvědčovalo tomu, že environmentální gramotnost je ve hře. Např́klad ještě v roce 2012 agentura Pearson, která vyhrála zakázku na tvorbu elektronických testů pro PISA 2015, prezentovala při představení koncepce výzkumu v roce 2015 rámec pro environmentální gramotnost, vedle rámců pro prírodovědnou gramotnost a pro týmovou spolupráci při řešení problémů (DeJong, 2012). 
Máme za to, že nezařazení environmentální gramotnosti do výzkumu PISA představuje pro rozvoj environmentální výchovy zmařenou obrovskou přiležitost. Je jistě pravda, že každé měření je zatíženo chybou, a výzkum PISA v tom není výjimkou. Jak uvádí Jana Straková, jako komplexní výběrové šetření je tento výzkum zatížen značnou výběrovou chybou a chybou měření (Straková, 2011). Viděli jsme v předloženém návrhu NAAEE, jak je celá oblast environmentální gramotnosti zúžena do několika klíčových složek, které mohou být $v$ šetření PISA částečně ověreny. $S$ vědomím všech těchto limitů by však data získaná o úrovni environmentální gramotnosti patnáctiletých v PISE 2015 představovala nedocenitelnou zpětnou vazbu pro další rozvoj environmentální výchovy. Ve většině zemí by se jednalo vůbec o první reprezentativní a komplexní výzkum věnující se environmentální gramotnosti, a to rovnou výzkum splňující nejpřísnější metodologické standardy kvality a navíc přinášející i mezinárodně srovnatelné výsledky. Lze předpokládat, že na mezinárodní úrovni i $v$ mnoha zemích by zjišttování úrovně environmentální gramotnosti v PISA 2015 rozproudilo odborné debaty o jejím vymezení, hodnocení i o vzdělávacích programech zaměřených na její rozvoj. PISA si vytvořila značné renomé a těší se pozornosti tvůrců vzdělávacích politik i médií a širší veřejnosti. Zařazení environmentální gramotnosti by tak mohlo přispět také $\mathrm{k}$ vyššímu uznání její důležitosti jak $v$ mezinárodním měřítku, tak $v$ jednotlivých zemích. Otázkou zůstává, zda nezařazením environmentální gramotnosti do výzkumu PISA v roce 2015 jsme ztratili tuto přiležitost nadobro, nebo je možné, že se jejího naplnění dočkáme někdy $v$ budoucnu.

\section{Závěr}

Bude zajímavé sledovat, jaký vliv si nové vymezení oblasti environmentální gramotnosti vytvoří navzdory tomu, že se environmentální gramotnost nakonec nestala součástí výzkumu PISA v roce 2015. Na tvorbě a připomínkování tohoto vymezení se podílela unikátní sestava odborníků, což umožnilo propojit poznatky a zkušenosti z tvorby předchozích rámců environmentální výchovy, z nedávných národních výzkumů environmentální gramotnosti v několika zemích a $z$ hodnocení gramotností v mezinárodním výzkumu PISA. Popis oblasti environmentální gramotnosti, který vytvořili, je $v$ nebývalé miře podložen výsledky výzkumů a další odbornou literaturou. Nové vymezení tak $v$ mnoha ohledech odráží to nejlepší z tradice anglosaského pojetí environmentální výchovy, ale i z moderního konceptu gramotností a jejich hodnocení. $Z$ těchto důvodů doporučujeme každému, kdo se zabývá hodnocením environmentální gramotnosti na různých úrovních, nebo kdo se bude snažit o nové definování oblasti environmentální výchovy, aby se s dokumentem NAAEE podrobně seznámil.

\section{Použitá literatura:}

- Broukalová, L., Broukal, V., Činčera, J., Daniš, P., Kažmierski, T., Kulich, J., Lupač, M., Medek, M. a Novák, M., (2011). Cíle a indikátory pro environmentální vzdělávání, výchovu a osvětu v České republice. Praha: Ministerstvo životního prostředí České republiky. Retrieved from http://www.mzp.cz/C1257458002F0DC7/cz/cile indikatory evvo dokument//\$FIL E/OEDN-Cile a indikatory EVVO-20110118.pdf

- Činčera, J. (2011). Doporučené očekávané výstupy pro environmentální výchovu. Envigogika, 6(2), 1802-3061. Retrieved from http://envigogika.cuni.cz/index.php/Envigogika/article/view/59

DOI: http://dx.doi.org/10.14712/18023061.59 
- Činčera, J., Štěpánek, P., (2007). Výzkum ekologické gramotnosti studentů středních odborných škol. Envigogika, 2(1), Retrieved from http://envigogika.cuni.cz/index.php/Envigogika/article/view/12 DOI: http://dx.doi.org/10.14712/18023061.12

- De Jong, , \& J. H. A. L, (2012). Framework for PISA 2015. Paper presented at 4th Annual Conference of Educational Research Center, Broumana, Lebanon. Retrieved from http://www.educationalrc.org/conference2012/PDF/Prof\%20John\%20de\%20Jong. pdf

- Dunlap, R. E., \& Van Liere, K. D. (1978). The "New Environmental Paradigm. Journal of Environmental Education, 9, 4, 10-19.

- Dvořáčková, S., Ryplová, R., (2012). Sonda environmentální gramotnosti studentů prírodovědně a ekologicky zaměřených oborů na Pedagogické fakult. Envigogika, 7(3), Retrieved from http://envigogika.cuni.cz/index.php/Envigogika/article/view/77

DOI: http://dx.doi.org/10.14712/18023061.77

- Franěk, M. (2012). Nature Relatedness Scale. Český překlad škály měříí spojení s prírodou. Envigogika, 7(1), Retrieved from http://envigogika.cuni.cz/index.php/Envigogika/article/view/69 DOI: http://dx.doi.org/10.14712/18023061.69

- Hollweg, K. S., Taylor, J. R., Bybee, R. W., Marcinkowski, T. J., McBETH, W. C., \& Zoido, P. (2011). Developing a framework for assessing environmental literacy. Washington, DC: NAAEE. Retrieved from http://www.naaee.net/sites/default/files/framework/DevFramewkAssessEnvLitOnli neEd.pdf

- Hungerford, H. R., \& Volk, T. L. (1990). Changing Learner Behavior Through Environmental Education. The Journal of Environmental Education, 21(3), 8-21.

- Matějček, T., \& Bartoš, J. (2012). Environmentální gramotnost učitelů a studentů učitelstv. Envigogika, 7(2), 1802-3061. Retrieved from http://envigogika.cuni.cz/index.php/Envigogika/article/view/75 DOI: http://dx.doi.org/10.14712/18023061.75

- NAAEE, (2000). Environmental Education Materials: Guidelines for Excellence Workbook. Washington. Retrieved from http://resources.spaces3.com/83a622d9c732-4c9a-8e31-aca1afa7a9b5.pdf

- NAAEE, (2004). Environmental Education Materials: Guidelines for Excellence. Washington. Retrieved from http://resources.spaces3.com/3725a5c0-f0ab-40399bd2-c5dbd9bcb34f.pdf

- NAAEE, (2009). Nonformal Environmental Education Programs: Guidelines for Excellence. Washington. Retrieved from http://resources.spaces3.com/b33925e669d6-4832-8442-5e3f32287b7b.pdf

- NAAEE, (2010). Excellence in Environmental Education: Guidelines for Learning (Pre K-12). Washington. Retrieved from http://resources.spaces3.com/89c197bfe630-42b0-ad9a-91fobc55c72d.pdf 
- NAAEE, (2010). Guidelines for the Preparation and Professinal Development of Environmental Educators. Washington. Retrieved from

http://resources.spaces3.com/e42d12db-f327-46ca-94c2-647060d23e74.pdf

- NAAEE, (2010). Early Childhood Environmental Education Program: Guidelines for Excellence. Washington. Retrieved from http://resources.spaces3.com/91ecfc062076-4e26-880d-2332e87b5caf.pdf

- OECD, (2005). The Definition and Selection of Key Competencies. Executive Summary. . Retrieved from http://www.oecd.org/pisa/35070367.pdf

- OECD, (2009). Green at 15? How 15-year-olds perform in environmental science and geoscience in PISA 2006. Paris: OECD Publishing.

- OECD, (2013). About PISA. . Retrieved from http://www.oecd.org/pisa/aboutpisa

- OECD, (2013). PISA 2015 Draft Frameworks. . Retrieved from http://www.oecd.org/pisa/pisaproducts/pisa2015draftframeworks.htm

- Palečková J. a kol, (2007). Hlavní zjištění výzkumu PISA 2006. Poradí si žáci s př́rodními vědami?. : Ústav pro informace ve vzdělávání.

- Orbis Scholae (2011). Ke kritice výzkumu PISA. Orbis Scholae, 2011(3), 123-127. Retrieved from http://www.orbisscholae.cz/archiv/2011/2011_3_07.pdf

- ÚIV, (2006). Koncepce prírodovědné gramotnosti ve výzkumu PISA 2006. Praha: Ústav pro informace ve vzdělávání.

- UNESCO, (1975). The Belgrade Charter. A Global Framework for Environmental Education. Paris: UNESCO. Retrieved from http://unesdoc.unesco.org/images/0001/000177/017772eb.pdf

- UNESCO, (1978). Intergovernmental Conference on Environmantal Education, Tbilisi, 14 - 26 October 1977. Final Report. ED/MD/49. Paris. Retrieved from http://unesdoc.unesco.org/images/0003/000327/032763eo.pdf 